\title{
Le Petit Nicolas and the Ontological in Schooling
}

\author{
Sharada Gade
}

\begin{abstract}
"School as a site for the production of persons" (Packer \& Greco-Brooks, 1999) is discussed in this article through an exploration of children's growth as students. Drawing on Nicholas' school stories from Rene Goscinny and Jean-Jacque Sempe's well-known series entitled, Le Petit Nicolas, the kind of people we could become as students and teachers, even if fictional, is portrayed to highlight the importance of personhood and/or the ontological in schooling.

In this article I examine the types of people we could become in school by attending to school stories, as exemplified by Nicholas' stories and voice from Goscinny and Sempe's well-known series entitled, Le Petit Nicolas. Consider, for example, Nicholas' portrayal of his classmate Cuthbert, in his story relating to taking a school photograph,

The photographer and his camera had arrived too, and our teacher told him to be quick about it or else we'd miss arithmetic, and Cuthbert, who is top of the class and teacher's pet, said it would be a great shame to miss arithmetic because he did so like arithmetic so much and he'd got all his sums done, and Eddie who is a very strong boy, wanted to punch Cuthbert's nose, only Cuthbert wears glasses so we can't thump him as much as we would like to. (Goscinny \& Sempe, 2005, p. 1)
\end{abstract}

Or Nicholas' tale about their getting monthly mark books,

And Mathew started to cry. Mathew is bottom of the class, and every month our teacher writes lots of things to him mum and dad in his mark book, and Mathew's mum and dad are cross and say he can't have any pudding or watch television. Mathew told me they've got so used to it by now that once a month his mum doesn't bother to make a pudding at all and his dad arranges to go next door to watch television. (Goscinny \& Sempe, 2005, p. 57)

As practitioners, it would not be difficult to recognize a Cuthbert, Eddie, Mathew, or Nicholas in our own school. And it would be easy to find parallels between Nicholas' repertoire of stories and tales that make comic sense in our own sociocultural contexts. Yet, I consider these to speak to the unceasing dialectic that lies between the many small rituals that constitute the wider practice of schooling in society, such as taking photographs or receiving monthly mark books, and the plethora of fun, exhilarating, frustrating, sad, and even tragic ways in which we experience schooling. Forming the memorable stuff of school life, these stories, as McCourt (2005) recounts in Teacher Man, tend to invariably follow us to dinner, to the movies, to the bathroom, and even to our beds. Moreover, I draw upon a literary model of psychology to discuss the importance of grasping the kind of people we become within schooling. Kozulin (1996) explains stories or literature more generally to serve as a prototype of human life itself and become a psychological tool with which we mediate our lived experiences. As Nicholas' portrayals exemplify, different aspects (e.g., students being top or bottom of the class or teacher's pet; or having harried parents 
at home) allow us to share experiences we come to associate with schooling when these are expressed through narratives or stories. Kozulin believes that literature deserves even greater attention, given its ability to represent human understanding. As skilfully crafted discourse, literature is a vital source for achieving cognitive maturity and changing the consciousness of readers.

A storied manner of understanding the self or personhood of students and teachers remains informed by insightful writings in the social sciences. A long-time proponent of narrative modes of thinking and knowing - in contrast to more logico-scientific ways-Bruner (1987) argues that stories are ways of describing lived time as well as possible lives. He maintains that life stories, whether autobiographical or helping to structure human experiences, can be narrated in many ways and examined over and over again. Olson (2007), however, questions our ability to realize this sense of the possible, affirming that schools are institutions that are organized to meet their goals effectively and economically. Calling for school reform to recognize this gap between the personal and the institutional, Olson seeks the study of schooling in anthropological terms so as to explore the socioeconomic climate in which students and teachers are situated.

Speaking to what he said was the predictable failure of school reform, Sarason (1990) highlighted two issues he found problematic. First, schools seemed to exist mainly for students. Sarason argued that only those schools which were conducive to the growth of teachers, would have them provide the same conditions for their own students. Second, students have come to accept two worlds, one inside school and another outside. With teaching geared largely to subject matter and not children, the world outside was far more stimulating and interesting, making the conception of school counterproductive to learning. Urging that schools be socially organized to enhance students' development, Bronfenbrenner (2005) calls for making human beings more human. Based on studies conducted in the early 1970s, Bronfenbrenner lamented that the US school institution had become increasingly isolated from the homes of students. With a decline in the number of neighborhood schools, parents and teachers were less likely to be friends, he pointed out. This problem was further aggravated by the way children were segregated in classes whose composition changed every year, resulting in students having little or no social identity of their own. I draw on the works of Bruner, Olson, Sarason, and Bronfenbrenner for two reasons: first, their arguments have great relevance to present-day schooling, and second, each of these scholars speaks to the need for understanding the personal and/or the ontological within everyday schooling.

Two writings by Packer discuss "school as a site for the production of persons" and the importance of ontological aspects, beyond the epistemological, in schooling. Packer's first study with Greco-Brooks (1999) examines the kind of changes children experience as they attend the first day of school in a small, poor, working-class, elementary school in an ethnically mixed community, in the rust belt of the US. Arriving at "Room 2" with cut-out paper bears, the teacher in this classroom sets about transforming children from home into her students at school. As persons they are soon defined as "boys and girls" who must pay attention, raise their hands when wanting to speak, and follow rules in relation to thinking in the classroom. A splitting is produced in the nature of their person, they argue, as the "I" who was interested in "my dog" is now transformed into a "you" interested in "pets and animals." 
Packer and Greco-Brooks underscore that such transformation in their being or person, demands ontological work on their part,

This new subject is subject to new demands about what must remain unsaid and undone. That impulses should not be acted on immediately, but must be delayed and deferred is a constant imperative in this first-grade classroom, as in many. Desire must be postponed - the students need to listen, not talk, and they need to wait, not act. The body is disciplined, as the child becomes member of a community quite different from the family, becomes one among equals. (p. 148)

The cultural and historical manner in which schools transform a member-of-family and produce a student-in-classroom, means that both students and teachers are not the same kind of person as well. Building on these notions, Packer's subsequent study with Goicoecha (2000) formalizes the importance of ontology, beyond the more commonly attended to epistemology in school. Since learning transforms the person and the social world, they believe that the study of both is worthwhile and necessary. As illustrated in Nicholas' stories, schooling fosters the production of persons-something which epistemic theories of learning often fail to address. My focus on Packer's writings and the importance of ontological aspects of schooling emerged from my taking action and coming to know students and their experiences, while collaborating with a teacher in her classroom (Gade, 2016). Recent scholarship in the Vygotskian tradition views the ontological to be part and parcel of the epistemological as humans transform their status quo (Stetsenko, 2013). However, in this article I discuss ontological issues against the backdrop of literature as psychological tool and the social identity of a cohort of students as they navigate the worlds both inside and outside school. Attending to the first person, I delve into the existential dilemmas of Nicholas and his mates, faced within the rough-and-tumble setting of their school and deftly portrayed in Goscinny and Sempe's action-packed narrative. I thus ask: "In what manner do Nicholas and his mates speak to the ontological or personhood in schooling?"

\section{A Nickname}

I now offer excerpts from the first of three stories in which Nicholas portrays the kind of persons he and his classmates become. While Nicholas had earlier identified Cuthbert as teacher's pet, in this story he and his mates come up with a nickname for one of their teachers, Mr. Goodman. Nicholas recounts,

So Mr Goodman took us all to our classroom. We call him Old Spuds, though not to his face of course. We call him Spuds because he is always saying, 'Boy, look me in the eye!' and potatoes have eyes. No, I didn't get it at first either, it was some of the older boys who explained it to me. Old Spuds has a big moustache and he is very strict; it's no good trying to play him up. So we were sorry he was going to look after us, but luckily when we got into our classroom he said, 'I can't stay, I have some work to do with the Head. Now, boys, look me in the eye and promise to behave.' So we all looked him in the eye and promised to behave. We nearly always do behave, anyway. (Goscinny \& Sempe, 2005, p. 17)

The story continues with Mr. Goodman allowing "the top of the class" to sit at the teacher's desk, so that he, in turn, could keep an eye on others while they do some revision. Cuthbert thus chooses to have his classmates do arithmetic and Mr. Goodman visits the class now and then. However, it is not long before 
pandemonium breaks out and a student who is on the lookout for Mr Goodman shouts, "It's Old Spuds!" Now, of course, Mr. Goodman wanted to know who called him that,

'Please, sir, it wasn't him, sir, it was Cuthbert who said Old Spuds!' cried Rufus.

'I never said Old Spuds! shouted Cuthbert.

'You did say Old Spuds. I heard you say Old Spuds quite clearly, you did say Old Spuds,

Old Spuds!'

'Very well, if this goes on you will all be kept in!' said Old Spuds.

'Why me, sir?' asked Alec. 'I never said Old Spuds!'

'I don't want to hear that ridiculous nickname any more, understand?' said Old Spuds.

He seemed ever so upset. .........

'What in the world is going on, Sp... Mr Goodman?' asked the Head.

(Goscinny \& Sempe, 2005, pp. 21-22)

Many aspects of the ways in which order is maintained in schools are exemplified in the above story. To begin with, Mr. Goodman asks his students to look him in the eye, so that they would keep the promise they were making to him. His allowing Cuthbert, an accomplished student, to sit at the teacher's desk and monitor his classmates is another-an order they attempt to of course disrupt. In using the nickname Old Spuds and in a Bakhtinain sense, Rufus and his classmates are able to do just that. This excerpt draws attention to the power differential at play between teachers and students in school more generally, one producing different kinds of persons. While we find Cuthbert acquiescing to school rules, others do not and cannot, since only one of them can be top of the class. In Alec not wanting to be kept back in class, wishing to maintain his innocence, he too, like Rufus, indulges in calling Mr. Goodman by his nickname over and over again, a ploy that is all too well known. In the Head making the same slip as students, Mr. Goodman's personhood as Old Spuds turns out to be a widely acknowledged fact in Nicholas' school.

\section{A Secret Code}

The second story relates to the inventiveness with which Nicholas and his mates attempt to overcome their being forbidden by their teacher to speak to one another during lessons. No matter how quietly they communicate with one another, either by whispering or by passing chits, he and his classmates get caught and are threatened with detention. Nicholas tells us,

That's why we liked the idea Geoffrey told us at break today.

'I've invented a secret code. It's great! Geoffrey said. 'Our gang are the only ones who'll be able to understand it.'

And he showed us. You made a different gesture for each letter; for instance, putting your finger on your nose was ' $a$ ', putting your finger on your left eye was ' $b$ ', putting your finger on your right eye was ' $\mathrm{c}^{\prime}$. There were different things for all the letters, like scratching your ear, or rubbing your chin or tapping your head, all the way through to the letter ' $z$ ', which was squinting. It was great! (Goscinny \& Sempe, 2007, pp. 103-104)

The story continues with Nicholas noting that Matthew was not happy with the secret code since the alphabet itself was a secret code to him, while Cuthbert, in contrast, had no interest in it at all. The other members of Nicholas' gang, however, teach themselves the code, even as they are caught by 
Mr. Miller, a new teacher who is only a bit older than the big boys. Once back in their classroom, all students are asked to copy down sums in their exercise notebooks, which their teacher puts up on the board. Meanwhile, Geoffrey starts to gesture and catches everyone's attention,

Geoffrey's message was ever so long, which meant we couldn't copy down the sums. We were afraid of missing some of the letters and not understanding the message, so of course we had to keep on looking at Geoffrey, and Geoffrey sits in the back row.

And then Geoffrey rubbed his right foot for ' $\mathrm{t}$ ' and put his tongue out for ' $\mathrm{h}$ ', and his jaw dropped, he stopped, we all turned around again and we saw that our teacher had stopped writing on the board and was watching Geoffrey.

'Yes, Geoffrey,' said our teacher. 'Like your friends, I am fascinated by your curious antics. But don't you think this has gone on long enough? Go and stand in the corner, you will not go out at break, and by tomorrow you will write out one hundred times, 'I must not act the fool in the class and be a bad influence on my friends, preventing them from working.' ........ It wasn't till next day Geoffrey told us what his message was. He'd been saying: 'Stop staring at me like that, you lot, or our teacher will notice something.' (Goscinny \& Sempe, 2007, pp. 106-107)

Despite the consequences that Geoffrey's use of the code may have had on Nicholas and his classmates, this story depicts loyalty in the personhood of children, as both students and classmates. In fact, one can argue that in the above episode, Nicholas and his gang are working against the splitting ${ }^{1}$ they experience between being friends and being students, as pointed out by Packer and Greco-Brooks. Yet Geoffrey's code, the learning of it and the subsequent use by the gang, followed by their teacher's threat of handing out punishment, all display the kind of persons their schooling demanded from each of them, involving ontological work that was both difficult and comical at the same time. As Olson (2007) asserts, these actions speak volumes about students' ways of dealing with various aspects of discipline and control, intrinsic to institutions like schools that are governed by efficiency and economy.

\section{An Interesting Project}

Nicholas' final story describes a "show-and-tell" project that his teacher is organizing. The story highlights the types of problems children experience as students under the watchful eyes of not one, but multiple teachers at school, who quote some more rules to the students and threaten them with serious consequences. Such governance is demanding of their personhood, as found below:

'We're going to do a project about very special things tomorrow,' our teacher told us. 'I want each of you to bring something interesting to school, preferably a travel souvenir. We'll discuss the objects you bring, and each of you will tell us where whatever he has brought comes from, and what it makes him think of. It will teach us general knowledge, geography and composition all at the same time.'

'What sort of things are we supposed to bring?' Matthew asked.

'I've just told you, Matthew!' said our teacher. 'Bring some interesting object ... something which tells a story. You know, a few years ago one of my pupils brought along a dinosaur bone his uncle had once dug up. Can anyone tell me anything about dinosaurs?'

(Goscinny \& Sempe, 2008, p. 71) 
On reaching home that day Nicholas tells his dad that he has been told to take something to school. This makes his dad express appreciation for the teacher's idea:

'I think these projects are an excellent idea.' said Dad.

'Having something there to look at means you'll never forget the lesson. Your teacher's very good, very up-to-date. Now let's think what you can take ...'

'Our teacher says it really ought to be a dinosaur bone,' I explained.

Dad looked surprised. 'A dinosaur bone?' he said. 'Well really! And just where do you think I'm going to find a dinosaur bone? No, Nicholas, I'm very sorry, but I'm afraid you'll have to make do with something simpler.'(Goscinny \& Sempe, 2008, pp. 71-72)

The father then suggests that Nicholas could take a large shell that the family had bought on vacation in Spindrift Island. On the following day Nicholas recounts,

When I got to school all our gang were there, and they asked me what I'd brought. 'What have you brought? I asked.

'I'm not going to show anyone mine till we're in class,' said Geoffrey. He likes to act mysterious.

The others weren't saying either, except for Jeremy, who showed us a knife. It was a fantastic knife!

'It's a paperknife,' Jeremy told us. 'My Uncle Andrew brought it back from Toledo for my Dad. Toledo's in Spain.'

And Old Spuds, who is one of our teachers, only that isn't his real name, well, Old Spuds saw Jeremy and he confiscated the paperknife, and he told Jeremy he'd told us a hundred times already not to bring dangerous objects to school.

'But, please, sir,' said Jeremy, 'our teacher told me to bring it.'

'Oh, did she?' said Old Spuds. 'Your teacher told you to bring this dangerous weapon to school? You amaze me! Right, not only am I confiscating it, I want you to write out fifty times, "I must not tell Mr Goodman lies when he asks me a question about a remarkably dangerous object which I have smuggled into school against the rules." There's no point in shouting at me, and the rest of you can just be quiet unless you want some lines too!'

And Old Spuds went off to ring the bell. We all stood in line, and Jeremy was still crying when we got into our classroom.

'This is a fine start, I must say!' said our teacher. 'Whatever is the matter, Jeremy?'

(Goscinny \& Sempe, 2008, pp. 73-74)

Eclipsing the minor lesson that may have been learnt about Toledo being in Spain, Jeremy appraises his teacher of his loss. Mentioning that bringing a knife to school was not exactly a good idea, their teacher promises to speak with Mr. Goodman. Just as Nicholas and his classmates have the opportunity to learn that Cuthbert's geography book was bought by his parents in Normandy, Geoffrey reports that a gold watch his father had bought him in Switzerland was missing. To everyone's relief, and by the end of this lesson, Jeremy is able to find his watch in the sleeve of his coat, just as Old Spuds returns Jeremy's penknife. Nicholas concludes that his was project "interesting," with his teacher too saying that she would not forget the things her students brought to school that day. Depicted in this episode is the kind of contradictions that arise when a teacher tries out new ideas in a school that are conducive to the growth of both teachers and students (Sarason, 1990). In moving beyond demands of effectiveness and efficiency (Olson, 2007), there is a rich portrayal of the gaps that exist between the personal and the 
institutional in reform-oriented efforts. It goes without saying that the sociological nature of efforts in terms of caring for shells picked up on vacation, on the one hand, and expensive gold watches, on the other, is something that teachers have to contend with in various ways that they might consider appropriate. The first person in schooling is thus deserving of all the attention that it is possible to give.

\section{The Ontological in Schooling}

I would be remiss if I didn't mention five key aspects in the writing of this article. First is my recognition that in borrowing from Nicholas' stories, I have unfortunately missed out on giving voice to girls with respect to schooling, something that is an all-too-sad reality in many parts of the world. However, such a representation is quite incidental and relates to my having bought Phaidon's recent editions of Le Petit Nicolas for a good summer read. In doing so, I followed up on fond memories of Nicholas' escapades, when these were read out by a colleague at our school in India in the late 1990s.

Second, as Bronfenbrenner (2005) points out, focusing on a greater concern for efficiency and economy in schools through rigid structures and routines can often result in dehumanizing us as people. As a teacher of science and mathematics, it was my memories of Nicholas which led me to more fully appreciate the ability of literature to change individual consciousness.

My third point relates to the fact that Le Petit Nicolas was originally written in French, and that the English translation might not depict Nicholas' predicaments in quite the same way. Yet, I consider Nicholas' world in English to be its own world, one that could be read for the many possibilities that it so aptly portrays. It is with deference to this that I have quoted Nicholas at length in his own words.

Fourth, I would like to sensitize my readers to the vital issue of ontology, inviting them to pay attention to the kind of people we become at school, as students and as teachers. For the arts-whether literature or other forms (Eisner, 2002) - have the ability to pay close attention to what is intended and slow down the perception of efficiency that can be put on the back burner for a while. It thereby becomes possible to focus upon our own personhood, in addition to that of Nicholas and his mates.

Finally, I would like to mention that ontological aspects may not be central for carrying out all types of research studies. While Elliott (1978) emphasizes the importance of ontological concerns in "educational research," this stands in contrast to what he terms "research on education." In the former, studies are carried out from the participants' perspective, phenomena are grasped with sensitizing concepts, and theory is generated in a posteriori manner. This is at odds with the latter, in which definitive concepts are deployed in an a priori manner and participants are largely objects of the study being conducted. 


\section{Note}

1. Having recognized the above, it would be fair to conclude that Nicholas' stories are able to convey the splitting in children that schooling brings about when a family member becomes a student in a classroom at a school. As Packer and Greco-Brooks (1999) point out, children's desire is here delayed in pursuit of societal pressure to become one among equals. However, such a transition is difficult for most children and fraught with ontological work on their part (i.e., being top of the class or forbidden to speak, on the one hand, and having to do lines or serve detention time, on the other). I am aware, too, that however convincing Nicholas' stories may be, I am not providing any empirical evidence in this article in terms of transcripts of audio/video recordings or excerpts from field notes as an educational researcher. Quite deliberately I am appealing to the literary and accessing the world of school as articulated by Goscinny and ably illustrated by Sempe. Their depictions of taking a school photograph, maintaining monthly mark books, having a nickname for a particular teacher, subverting a stifling system of order, conducting routine show-and-tell activities in the classroom, are all aspects we can envision, even if they differ from what may transpire in own schools. In drawing on the tales of Nicholas and his mates, I am alluding to the numerous stories that we readers may also have about schooling, tucked away somewhere or stumbled upon in our numerous individual journeys. Storytelling and stories, be they at our homes or in classrooms, are fertile places for us to explore and relive our human condition. And it is within these stories that our existential and/or ontological concerns come to vivid life in what Bruner (1997) identifies as the work of the left hand. Like Bruner, I believe human feelings, intuition and the arts — which the left hand as a dreamer has come to widely symbolize-need just as much attention as the rationality, discipline, and the sciences heralded by the right hand as a doer. Meanwhile, the current emphasis on cognitive and epistemological aspects at the expense of personal and ontological components in contemporary schooling further echoes Bruner, who said:

Perhaps the moment is uniquely propitious for the left hand, for a left hand that might tempt the right to draw freshly again, as in art school when the task is to find a means of imparting new life to a hand that has become too stiff with technique, too far from the scanning eye. (p. 8)

By this is meant a vital reclaiming of epistemology so as to include ontology in the societal practice of schooling. For it cannot be lost on us that we both are and become somebody in our respective journeys in life, whose myriad experiences we need to examine not only for the here and now, but also for another day.

\section{References}

Bronfenbrenner, U. (2005). Making human beings human: Bioecological perspectives on human development. Thousand Oaks, CA: Sage Publications.

Bruner, J. (1987). Life as narrative. In P. Atkinson \& S. Delamont (Eds.), Narrative methods: Volume 1 (pp. 99-115). Oxford, UK: Sage publications.

Bruner, J. (1997). On knowing: Essays for the left hand. Cambridge, MA: Harvard University Press.

Eisner, E. (2002). The arts and the creation of mind. New Haven, CT: Yale University Press. 
Elliott, J. (1978/2007). Classroom research: Science or commonsense. In J. Elliot (Ed.), Reflecting where the action is: The selected works of John Elliott (pp. 91-98). Wiltshire, UK: Routledge.

Gade, S. (2016) Oneself in practitioner research, with Vygotsky and Bakhtin. Reflective Practice, 17(4), 403-414.

Goscinny, R., \& Sempe, J-J. (2005). Nicholas. London, UK: Phaidon Press Limited.

Goscinny, R., \& Sempe, J-J. (2007). Nicholas and the gang. London, UK: Phaidon Press Limited.

Goscinny, R., \& Sempe, J-J. (2008). Nicholas in trouble. London, UK: Phaidon, Press Limited.

Kozulin, A. (1996). A literary model for psychology. In D. Hicks (Ed.), Discourse, learning and schooling (pp. 145-164). Cambridge, MA: Cambridge University Press.

McCourt, F. (2005). Teacher man: A memoir. New York, NY: Scribner

Olson, D. R. (2007). Jerome Bruner: The cognitive revolution in educational theory. Norfolk, UK: Continuum.

Packer, M., \& Goicoechea, J. (2000). Sociocultural and constructivist theories of learning: Ontology, not just epistemology. Educational Psychologist, 35, 227-241.

Packer, M. J., \& Greco-Brooks, D. (1999). School as a site for the production of persons. Journal of Constructivist Psychology, 12(2), 133-149.

Sarason, S. (1990). The predictable failure of educational reform: Can we change the course before it's too late. San Francisco, CA: Jossey-Bass Publishers.

Stetsenko, A. (2013). The challenge of individuality in cultural-historical activity theory: "Collectividual" dialectics from a transformative activist stance. Outlines: Critical Practical Studies, 14(2), 7-28.

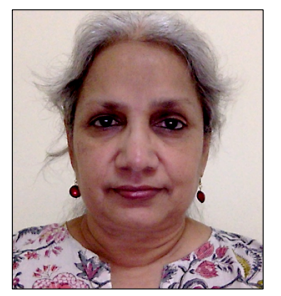

Sharada Gade is an independent researcher in Hyderabad, India and also Visiting Faculty at the Tata Institute of Social Sciences (TISS). Her collaborative work with middle school teachers, most recently in Sweden, has a three-fold focus: CHAT perspectives, practitioner inquiry, and mathematics/science education. Following doctoral work at the University of Agder, Kristiansand, Norway, Sharada has held visiting postdoctoral fellowships at Homi Bhabha Centre for Science Education, Mumbai, India; Umeå Mathematics Education Research Centre, Umeå University, Sweden; The Graduate Centre, City University of New York, USA; and the Department of Education, University of Oxford, UK. 
166 | LEARNing Landscapes | Spring 2018, Vol. 11 No. 2 